\title{
WIERSZO-PIOSENKI I SPEKTAKLO-KONCERTY - MEDIALNE ZAWIROWANIA W TWÓRCZOŚCI MARCINA ŚWIETLICKIEGO
}

\author{
MALWINA MUS*
}

Na początku była literatura. Zasady jej funkcjonowania ukształtowały nowe praktyki komunikacyjne, jakie powstały w XX wieku. Wzajemną zależność w trafny sposób pokazuje Maryla Hopfinger, mówiąc że literatura

wśród wielu funkcji pełni również taką, że stanowi układ odniesienia dla zmian i zakorzenia nowe zjawiska w tradycji. [...] co najmniej ułatwia rozumienie, interpretację mechanizmów zmiany i ciągłości. Jej wyjątkowość polega i na tym, że była źródłem wzorów dla innych dziedzin życia i sztuki, dla sceny i dla sztalug, zakorzeniała w tradycji obraz fotograficzny oraz kino i film, wzbogacała repertuar radia i telewizji. Zdaje się niewyczerpaną skarbnicą pomysłów i scenariuszy dla wszystkich mediów ${ }^{1}$.

Zarazem sama literatura również nie istnieje w próżni, ale w wyraźny sposób reaguje na zmiany, jakie zachodzą w innych dziedzinach sztuki, absorbując je. Szczególny wpływ na literaturę miał rozwój kina i sztuki filmowej, które uruchomiło u odbiorców jednoczesną percepcję audialną i wizualną. Ekspansja nowych mediów w dziedzinę literatury odbywa się zarówno na płaszczyźnie formy, jak i tematyki. Same media z kolei mogą być rozumiane dwojako: szerzej - w charakterze środków masowego przekazu (prasa, telewizja, Internet, radio), ale także precyzyjniej - jako specyficzna wiązka cech danego dzieła artystycznego². Stosowanie przez poetę chwytów rodem z innej dziedziny sztuki ma wówczas

* Malwina Mus - doktorantka, Wydział Polonistyki UJ.

${ }^{1}$ M. Hop fing er, Literatura elektroniczna [w:] te jże, Literatura i media po 1989 r., Warszawa 2010, s. 172.

2 Takie rozumienie mediów proponuje Konrad Chmielecki w swojej koncepcji es te ty ki intermedialności, która „spełnia uniwersalistyczny warunek traktowania sztuki bez jakichkolwiek podziałów. Ponadto istnienie mediów zakłada możliwość wzajemnej wymiany nie tylko informacji, ale także środków wyrazu, którymi media się posługują. Ten warunek prowadzi w prostej linii do nawiązania relacji intermedialnych i przyjęcia wobec sztuki perspektywy komunikacyjnej, a w konsekwencji - widzenia jednego medium poprzez drugie" (K. Chmielecki, Koncepcja teoretyczna estetyki intermedialności [w:] i de m, Estetyka intermedialności, Kraków 2008, s. 54, podkreślenie - M. M.). 
konsekwencje dla odbioru i przesłania utworu. W dalszej części swojego wywodu zamierzam pokazać, jak głęboko doświadczenie nowych mediów odbiło się w strukturze poezji Marcina Świetlickiego, a następnie przedstawić, jak zmiana medium, jako nośnika pewnej treści, wpływać może na kształtowanie się jej sensu.

\section{MEDIALNE MIESZANKI - POEZJA ZAPATRZONA W NOWE MEDIA}

Rzeczywistość nowych mediów, stanowczo wkraczając w życie każdego człowieka, stała się ważnym tematem literatury współczesnej. W twórczości Marcina Świetlickiego zwykle bywa negatywnym punktem odniesienia, czego interesującym przykładem jest wiersz Wstęp. Utwór otwierający debiut poety przedstawia sytuację rozpiętą między dwiema czasoprzestrzeniami: mityczną i realistyczną, które niepostrzeżenie mieszają się ze sobą i splatają. Opisany akt stworzenia Abla (głosu mówiącego w wierszu) jest umieszczony w sieci odniesień do Księgi Genesis. Kreacja odbywa się przy pomocy słów, poprzez nazwanie rzeczy dotąd nienazwanych (,Dam mu na imię Abel - powiedział ten obcy/ człowiek, którego potem tak straszliwie trudno/ będzie n a z y w a ć ojcem”, „Wieczór - gdy to zrobili i nadali imię")"3. Mowa, język jest materią do tworzenia literatury; z kolei księga natchniona, z której parafrazą mamy w tym przypadku do czynienia, jest zarazem dziełem literackim. Na myśl przychodzi fraza „na początku było Słowo", która czyni z języka atrybut boski, traktuje tekst jako namacalną reprezentację wartości metafizycznych. Nie bez znaczenia tego typu konotacje zawiera utwór inicjujący całą wydawniczą spuściznę Świetlickiego; można go potraktować jako metawypowiedź na temat funkcji poezji i szerzej - literatury.

Motywy genezyjskie, podobnie jak imię bohatera, występują tu w konkretnej roli - wszystkie znamionują grzech, wstyd, sytuację ofiary. Tworzą one rzeczywistość symboliczną będącą jakoby rewersem realnego świata - prozaicznego, obskurnego, płytkiego, którego elementami są nowe media. W trybie dosłownym, w chwili gdy rodzice bohatera odbywali akt płciowy, w którego konsekwencji narodził się Abel, ,[...] ojciec ojca kaszlał i krzyczał za ścianą/ w obcym języku klątwy, a radio trzeszczało,/ trzeszczało i huczało niczym miecz ognisty". Dźwięk radia wprowadza do obrazu niepokój, widmo grzechu, przewinienia, przywołuje wątki apokaliptyczne. W opisie pomieszczenia pojawia się także „,...] miesięcznik/ «Ty i ja», który leżał na stole pod lampą/ - otwarty, wcale nie przypadkiem, na pierwszej stronicy”. Słowo „stronica” kontrastuje z własnym desygnatem, bardziej niż z kolorowym czasopismem kojarzy się z opasłą, mądrą księgą, taką jak Biblia.

${ }^{3}$ M. Świetlicki, Wstęp [w:] te go ż, Wiersze, Kraków 2011, s. 11. Wszystkie przywołane w tekście wiersze cytuję za tym wydaniem. W nawiasach podaję tytuł utworu oraz numer strony z edycji zbiorowej (podkreślenia - M. M.; wskazują na związek między działaniem a nazywaniem). 
Paralela między odniesieniami do Księgi Genesis otwierającej Stary Testament, utworem inicjującym debiutancki tom poetycki Marcina Świetlickiego, i pierwszą kartką miesięcznika „Ty i ja” kompromituje ostatnie ogniwo ciągu, podkreśla jego miałkość, brak wartości naddanych, zdolności do przewodzenia metafizyki (brak właściwości medialnych - w tradycyjnym rozumieniu tego terminu).

Podobnych refleksji wynikających z tematycznego ujęcia problematyki nowych mediów jest u Świetlickiego więcej, by przywołać chociażby takie wiersze jak Casablanca czy $M$ - między dwudziesta drugq a czwartq nad ranem, w których film i gwiazdy filmowe - choć są pozytywnym punktem odniesienia, choć w głosie mówiącym wybrzmiewa fascynacja kinem - zawsze przegrywają w konfrontacji z prawdziwą rzeczywistością. „To się nie zdarza naprawdę" (M - między dwudziestq drugq a czwartq nad ranem, 197), a aktorzy kreujący nieśmiertelne role, starzeją się i tracą swoją atrakcyjność.

Utwór Casablanca wskazuje jednak na drugą, afirmatywną możliwość konszachtów Świetlickiego z nowymi mediami. W wyznaniu ,,To ja/ zabiłem Laurę Palmer" (Casablanca, 152) ujawnia się już nie tylko filmowa erudycja głosu mówiącego, ale także wpływ popkultury, której największym nośnikiem są nowe media, na język poetycki. Laura Palmer to fikcyjna postać, bohaterka serialu telewizyjnego Miasteczko Twin Peaks, wokół zabójstwa której skoncentrowana jest akcja filmu. Zacytowane przez Świetlickiego powiedzenie było często, prześmiewczo używane przez odbiorców w czasach emisji produkcji Davida Lyncha i Marka Frosta. O jego popularności może świadczyć fakt, że masowo produkowano T-shirty z nadrukowanym tekstem. Tym sposobem popkultura wdziera się w poezję Świetlickiego, podmiot wierszy mówi głosem telewizji, radia, dialogami filmowymi, hasłami reklamowymi. Przywołane wprost zwroty to bardzo czytelne symptomy przemian, jakim język poetycki uległ pod wpływem nowych mediów. Proces ten zachodzi jednak nie tylko w płytkich warstwach języka, ale także wnika w głębokie struktury konstrukcji utworów poetyckich.

Bohaterem wiersza Karol Kot jest słynny „wampir z Krakowa”, który budził strach wśród mieszkańców Małopolski w latach 60. XX w. Utwór nawiązuje do autentycznych wydarzeń, jakie przenikały do powszechnej świadomości za pomocą gazet i ówczesnych środków masowego przekazu - zgadzają się personalia ofiar, czas i miejsce popełnionych zbrodni ${ }^{4}$. Podobnie jak londyński Kuba Rozpruwacz stał się bohaterem kultury masowej, tak „krakowski wampir” posiada wszelkie cechy, by nim zostać. Poeta finguje przemyślenia mordercy w chwili zamachu, bazując na informacjach zawartych w wywiadzie z Karolem Kotem ${ }^{5}$.

${ }^{4}$ Marcin Świetlicki wydaje się być żywo zainteresowany postacią Karola Kota, o czym może świadczyć fakt, że morderca przewija się przez fabułę kryminału Dwanaście, w którą wplecione są zarazem fragmenty wywiadu $\mathrm{z}$ nim.

${ }^{5}$ Rozmowa z Karolem Kotem, online. Protokół dostępu: web.archive.org/web/200809151 53104/http://zbrodnia.killer.radom.net/zbrodnia.php?dzial=mordercy\&dane=KotKarol, 20 maja 2012 r. 
Marcin Świetlicki w czasach, gdy jeszcze nie publikował kryminałów prozą (wiersz pochodzi z tomu Schizma, wydanego w 1994 r.), napisał kryminał wierszem, zapożyczając środki wyrazu z medium filmowego.

Konstrukcja wiersza odpowiada opowieści snutej „okiem kamery”. Rozpoczyna się od zarysowania szerokich plenerów, po czym coraz bardziej i bardziej zawęża obszar swojego oglądu, zatrzymując się na najmniejszym, ale też najistotniejszym szczególe, jakim jest ukryty pod ubraniem nóż.

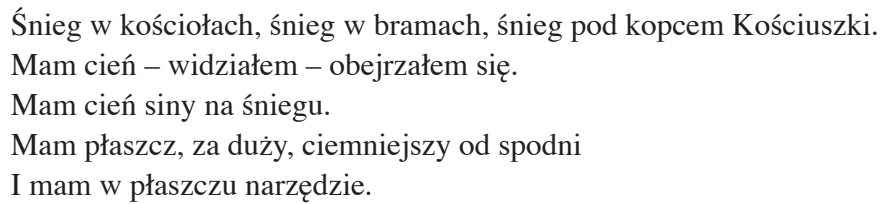

[Karol Kot, 102]

Opisy przedmiotów wydają się zbyt szczegółowe jak na poezję, natomiast wyraźnie oddziałują na zmysł wzroku czytelnika, starają się - podobnie jak w medium filmowym - dokładnie zaprezentować świat przedstawiony, nie pozostawiając czytelnikowi miejsca na samodzielne dookreślenia i dywagacje. W kolejnej zwrotce opis samego zamachu jest wyraźnie inspirowany filmową techniką szybkiego montażu. Rwane, krótkie słowa - początkowo w formie rozkazów, następnie opisujące otoczenie - oddają gwałtowność, dramaturgię akcji. Mają charakter dialogu mordercy z ofiarą (czy raczej monologu mordercy wobec ofiary), następnie zaś oddają wrażenia wzrokowe i słuchowe kata (dla osób znających postać Karola Kota także smakowe - powszechnie wiadomo, że morderca lubił po zakończonej napaści oblizywać ciepłą krew z noża). Prezentują wydarzenie z perspektywy aktanta, jak w filmach, w których świat postrzegany jest przez widza „oczami głównego bohatera”, będącego zarazem narratorem opowieści (taki sposób filmowego przedstawiania wydarzeń został z kolei zapożyczony z powieściowej techniki narracji pierwszoosobowej).

Ostatnia zwrotka opisuje drugi udany zamach Karola Kota, zakończony śmiercią 11-letniego chłopca. Podobnie jak w poprzednich wersach, tekst stara się oddać natłok myśli mordercy - co się okazuje - niezwykle trywialnych jak na sytuację: „Guzik z orzełkiem. Trener/ sekcji strzeleckiej stwierdził, że nie mogę/ reprezentować. Wziąłem duży rozmach”. Przemyślenia można jednak potraktować jak autorski komentarz na temat pobudek zabójcy, który zadając śmierć swoim ofiarom, mógł rekompensować sobie niepowodzenia osobiste, starać się podnieść zaniżone poczucie własnej wartości.

Poszczególne zwrotki wiersza są dość dosłowne, unikają metaforyki na rzecz jasności przekazu, wyrazistości obrazu, oddziałania na zmysły odbiorcy, wciągnięcia go w wir wydarzeń, maksymalnego uwiarygodnienia opisanych sytuacji. Konieczność interpretacji wprowadzają w zasadzie dopiero ostatnie wersy: „,...] i ściąłem jednocześnie: chłopca, śnieg, powietrze,/ swój kręgosłup, łodygę, śnieg 
pada, maszeruję przez sen, // mnożę się". Alogiczny ciąg skojarzeń może wskazywać na ekstazę, nagłe zamroczenie jasności umysłu napastnika (w wywiadzie Kot opisuje stan upojenia, rozluźnienia po każdorazowym zamachu), ale także swojego rodzaju utożsamienie się z ofiarą (rozszczepienie, rozmnożenie, współodczuwanie), symboliczne zadawanie sobie śmierci każdym ciosem wymierzonym w drugiego człowieka.

Rekonstrukcja psychiki zabójcy zaproponowana przez Świetlickiego ukazuje Kota jako osobę złą z natury, zwyrodnialca, dla którego czynów nie sposób znaleźć sensownych motywacji. Jego osobowość wydaje się całkowicie zdeterminowana jakąśs nieznaną siłą, przeczącą ludzkiej naturze. Sam Karol nie mógł mieć wpływu na swój charakter, samodzielnie go w sobie nie ukształtował, ale niejako został nim obarczony, naznaczony. Motyw pierwotnej, niezawinionej skazy rodzi skojarzenie między Karolem Kotem a Ablem - głosem mówiącym w omawianym uprzednio wierszu Wstęp, zaś poczynania Kota upodabniają go do biblijnego zabójcy - Kaina. Tym samym Świetlicki wskazuje na paradoksalną esencjonalną bliskość obu kulturowo przeciwstawianych sobie postaci, widzi w Karolu Kocie zarówno kata, jak i ofiarę.

Wiersz ukształtowany na zasadzie migawki z filmu kryminalnego jest niezwykle sugestywny, operowanie słowem schodzi w nim na drugi plan wobec operowania obrazem poetyckim, który narzuca odbiorcy specyficzny tryb percepcji. Mamy do czynienia z przeniesieniem środka ciężkości - wiersz zamiast być reprezentantem uczuć głosu mówiącego, wywołuje określone odczucia u odbiorcy. Nie tyle odczucia emocjonalne, ile odruchy fizjologiczne, związane ze strachem, lękiem, poczuciem zagrożenia lub - przyjmując perspektywę Kota - triumfu, ekstazy. Słowa stają się bodźcem do wydzielenia adrenaliny, konstruują sytuację, w którą ,wrzucony” zostaje czytelnik. Tym samym możemy mówić o zaistnieniu wiersza w obrębie estetyki performatywnej, której istotą jest kwestionowanie granicy między życiem a sztuką, fizyczna obecność odbiorcy w przestrzeni dzieła sztuki, a co za tym idzie - oddziaływanie artefaktu na jego cielesność, zmysły.

W przypadku Karola Kota filmowość wiersza nie kształtuje radykalnie jego znaczenia, modyfikuje za to status i kompetencje odbiorcy oraz aktywizuje performatywny potencjał poezji Świetlickiego. W dalszej części swojego szkicu postaram się pokazać, w jaki sposób Marcin Świetlicki wykorzystuje znaczeniotwórcze możliwości różnych mediów w realizacji jednego utworu.

\section{WIERSZO-PIOSENKI}

Koncepcja estetyki intermedialności Konrada Chmieleckiego bazuje na zaczerpniętym od Timothy’ego Binkleya rozumieniu medium, które ,nie jest materiałem fizycznym, ale jedynie konwencją wyznaczającą medialną sferę pośredniczącą między materiałem fizycznym, z którego zostało wykonane dzieło sztuki, 
a wartościami estetycznymi, które ono ze sobą niesie" gający na „,przełożeniu” utworu z jednego medium na drugie, każdorazowo skutkuje zmianą konwencji odczytywania jego treści; pewne cechy pierwotnej wersji artefaktu ulegają wyostrzeniu, inne zostają pominięte. Utwór będący punktem wyjścia wszelkich medialnych przemian musi dodatkowo posiadać potencjał pozwalający przedstawić jego treść za pomocą odmiennych środków wyrazu. Rzadko się zdarza, by transpozycji medialnej dokonywał autor tekstu bazowego, dlatego efekt finalny adaptacji jest w pewnym sensie interpretacją jej twórcy. $\mathrm{Na}$ tym tle postacią wyjątkową jest Marcin Świetlicki. Poeta posiada niezwykłą medialną wrażliwość przejawiającą się w pisaniu wierszy, które stanowią zarazem teksty nagrywanych przez niego piosenek, oraz w wykonywaniu ich na scenie w ramach parateatralnych koncertów. Utwór, przechodząc drogę od tomu poetyckiego do sceny rockowej, wielokrotnie zmienia swój status medialny. Odci$s k i$ najlepiej ilustrują tego typu przemiany nie tylko dlatego, że zostały poddane trójstopniowym (wliczając teatralną adaptację twórczości Świetlickiego - czterostopniowym) medialnym przekształceniom, ale także na ich poszczególnych etapach zyskiwały coraz to nowe znaczenia nadbudowane na tekście bazowym za pomocą środków wyrazu charakterystycznych dla konkretnego medium.

Wiersz znalazł się w tomie Pieśni profana z 1998 roku i został opatrzony podtytułem: (jedna z wielu wersji); ma niezwykle swobodną, gawędziarską formę, która sprzyja mnożeniu rzeczonych wariantów. Swoboda wpisana w konstrukcję tekstu została skrzętnie wykorzystana przez Świetlickiego w ramach muzycznej oprawy wiersza, a następnie podczas jego scenicznych wykonań, o czym szerzej w dalszej części szkicu. Odciski to wiersz, w którym występują bohaterowie oraz wszechwiedzący narrator trzecioosobowy, co upodabnia utwór do poematu epickiego - gatunku wywodzącego się z ustnej tradycji epickiej i w starożytności przeznaczonego do wokalnej realizacji przez wędrownego śpiewaka. Poszczególne wykonania różniły się między sobą, posiadały jednak wspólny schemat fabularny, a jego przedstawienie ułatwiały bardowi sztywne frazy zawarte w tekście i stanowiące swojego rodzaju punkty orientacyjne. Na tej płaszczyźnie ujawniają się zupełnie nieoczekiwane podobieństwa między wierszem Świetlickiego a poematem homeryckim. Podobieństwa, co istotne, nie tematyczne, nie tyle nawet konstrukcyjne, ile - by tak rzec - metodologiczne. „Punktami orientacyjnymi” Odcisków są wielokrotnie przewijające się przez cały utwór zwroty do odbiorców (,Nno. Proszę sobie wyobrazić” - Odciski, 254) oraz metateksowe (np. „Dlaczegóż by nie druga połowa lat osiemdziesiątych?/ Dlaczegóż by nie?”). Powtarza się także dobitny refren: GOTUJ SIĘ, KURWO, GOTUJ./ WYPIJE I PÓJDZIE/ W MROK, w którym bodaj najwyraźniej uwidacznia się dominanta kompozycyjna całości - ironia. Pomiędzy frazami rozgrywa się akcja utworu nakreślająca możliwe znaczenia wyrażenia zapisanego majuskułą.

${ }^{6}$ K. Chmielecki, op. cit., s. 68. 
Do mężczyzny przychodzi w odwiedziny kobieta, z którą kiedyś łączyła go pewna niesprecyzowana relacja. $Z$ jej zachowania można wnioskować, że wiąże duże nadzieje ze spotkaniem. Mężczyzna wpuszcza ją do środka, bo - jak wspomina - jest dobrze wychowany. W rzeczywistości górę bierze jego nieasertywność, lęk, a może nawet poczucie winy wobec kobiety. Pani zachowuje się nadspodziewanie spokojnie, stara się zrobić wrażenie na gospodarzu - poprawia włosy, ładnie wygląda, „Dotyka/ jego rzeczy, które/ nigdy nie będą jej”, w końcu zasypia. Propozycja kawy, złożona przez mężczyznę, w rzeczywistości była tylko pretekstem, by opuścić pokój i zebrać myśli. Bohater obmyśla histeryczny plan - pragnie jak najszybciej pozbyć się gościa, po czym urwać z nim wszelki kontakt: „Ja nie mam telefonu./ Ona nie ma telefonu./ Założę drugi zamek./ Wyłączę domofon./ Wyrzucę klucz. Wyjadę". Najpierw musi się jednak zagrzać woda w czajniku, która dziwnym zbiegiem okoliczności, mimo upływu czasu, pozostaje zimna.

W zarysowanym kontekście słowa refrenu można rozumieć dwojako. Rozkaz prawdopodobnie jest skierowany do wody i wyraża skrajne zniecierpliwienie i frustrację mężczyzny; ale może także być interpretowany zgodnie z mechanizmem działania synekdochy - wówczas mężczyzna przenosi na wodę swoje odczucia wobec kobiety. Tak rozumiany tekst zmienia się w pogróżkę pod jej adresem, stanowi niewybredny komentarz na temat jej prowadzenia się, świadczy o stosunku bohatera do kobiet w ogóle, o jego niedojrzałości, mizoginii itd. Z kolei bohaterka utworu, od spotkania z którą pragnie się wymigać głos mówiący, niekonkretna Ona, może być żywą istotą zredukowaną w świadomości mężczyzny-bawidamka do biologiczno-seksualnej funkcji; ale równie dobrze można w tej figurze dopatrywać się kostuchy odwiedzającej upiornego bohatera, przypominającej mu o jego statusie z pogranicza życia i śmierci ${ }^{7}$. W zasadzie dla każdego z tych wariantów można znaleźć uzasadnienie w treści wiersza. W zależności od tego, który trop interpretacyjny uzna się za wiodący, zmienia się ogólny wydźwięk i znaczenie utworu: w równym stopniu można go traktować jako tekst o zabarwieniu komicznym, jak i tragicznym; zapatrzony w filmowy melodramat (a może nawet będący parodią melodramatu) horror, jak i ponury dramat psychologiczny. Przestrzeń literacka pozwala na tego typu rozdźwięk, który zatraca się przy wykorzystaniu wiersza jako tekstu piosenki.

Utwór Odciski znalazł się na płycie Świetlików pt. Perły przed wieprze z 1999 r. ${ }^{8}$ Publikacja wiersza zbiegła się zatem w czasie z jego muzycznym opracowaniem. Pojawia się pytanie, co było pierwsze: wiersz czy piosenka lub też: czym różni się wiersz od piosenki. Z rozmowy ze Stanisławem Beresiem wynika, że Świetlicki kiedyś zdecydowanie różnicował oba media, natomiast obec-

${ }^{7}$ Więcej na temat konstrukcji podmiotu mówiącego, jako upiora w wierszach Marcina Świetlickiego [w:] Mistrz świata. Szkice o twórczości Marcina Świetlickiego, red. P. Śliwiński, Poznań 2011.

8 Świetliki, [CD], Perły przed wieprze, Music Corner 1999 r. 
nie (2002 r.) - jak powiada - ,[...] zmierzam do czegoś takiego, co by było jednocześnie piosenką i wierszem. A nawet jednocześnie teatrem, prozą, poezją, filmem, czyli każdą z możliwych dziedzin sztuki. To by było nawet śmieszne - w krótkiej formie pomieścić wszystkie gatunki naraz"9. O poetycko-filmowych i poetycko-prozatorskich filiacjach twórczości Świetlickiego już wspominałam, czas najwyższy prześledzić, jak w materii językowej realizują się kolejne wymienione przez poetę gatunki medialne i odwrotnie - jak wiersz może zaistnieć w przestrzeni mediów innych niż literatura.

Na potrzeby piosenki Odciski zmieniły nieco swoją treść. Biorąc pod uwagę specyficzny rodzaj śpiewu Świetlickiego, którego melorecytacja z nonszalancją odnosi się do podkładu muzycznego, różnice nie były podyktowane wyłącznie ograniczeniami melodii. W porównaniu do oryginału, tekst piosenki zawiera więcej partii dialogowych. Słysząc stukanie do drzwi, bohater myśli: „Kogo znowu licho niesie", kobieta stojąc przed drzwiami, dodaje sobie otuchy słowami: „Przeczeszemy się i jedziemy” itd. Wypowiedzi postaci „udramatyczniają” tekst, wzmacniają i tak w nim obecny potencjał teatralny. Uwypuklona zostaje również hipotetyczność przedstawionej sytuacji. Oprócz inicjalnego: „Nno. Proszę sobie wyobrazić" w tekście pojawia się zwielokrotniona ilość refleksji odautorskich skonstruowanych według schematu: „Dlaczegóż by nie”, które poddają w wątpliwość opisane zdarzenie. Jawny akt kreacyjny sprawia, że bardziej istotna niż desygnat, staje się sama sytuacja snucia opowieści, wyznaczająca przestrzeń dzieła sztuki (na początku było słowo!). W przestrzeni tej funkcjonuje głos mówiący oraz odbiorca, słuchacz ponurej historii. To do niego autor ,puszcza oczko” w słowach, które różnicują tekst piosenki od słów wiersza: „Wtedy istnieli mężczyźni i kobiety./ Teraz nie wiadomo co istnieje”, „Wtedy mężczyźni palili papierosy”. Ironia tych wyrażeń polega na przywoływaniu czasów heroicznych bohaterów, pełnowartościowych reprezentantów swoich płci, i umieszczeniu ich w sytuacji przeczącej tej charakterystyce. Podobnie jak w przypadku wiersza, pojawiają się zatem dwie możliwości odczytywania utworu - na sposób komiczny lub tragiczny - jednak melodia piosenki ukierunkowuje interpretację.

Mityzacja przeszłości idzie tu w parze z poczuciem melancholii, rozumianej jako świadomość utraty, niedostępności tego, co upragnione. Melancholijny nastrój wprowadza zawodzenie saksofonu przy ogólnej oszczędności instrumentarium, a także zachrypnięty, chwilami demoniczny głos Świetlickiego. Wokal poety ze wszystkimi swoimi odcieniami, szepto-krzykami jest nie tylko nośnikiem treści, ale także wskaźnikiem jej interpretacji. Wyraźne modulacje pozwalają odróżnić żart od spraw poważnych, co nie zawsze jest możliwe w kontakcie z tekstem pisanym. Ponadto głos Świetlickiego ,gra”, wchodzi w role, inscenizuje dialog między dwiema postaciami. Kwestie mężczyzny są wypowiadane

${ }^{9}$ S. Bereś, Poeta czynny do odwołania - rozmowa z Marcinem Świetlickim [w:] te go ż, Historia literatury polskiej w rozmowach. XX-XXI wiek, Warszawa 2002, s. 444. 
w sposób neutralny, oficjalny, podczas gdy „Tak, tak, napiję się” kobiety jest nasycone emocjami i namiętnością. Dopiero w tym momencie, w czwartej minucie piosenki niezwykle prosta linia melodyczna nieco się komplikuje, a miarowe uderzenia perkusji i melancholijne brzmienie saksofonu zostają zmącone przez nieco optymistyczniejszą, nie przystającą do całości partię gitarową. Akompaniuje ona wypowiedzi kobiety, wskazując na jej pozytywne, pełne wiary i - co ostatecznie się okazuje - naiwności nastawienie. Wypowiedź bohaterki zostaje skwitowana ledwo słyszalnym chichotem narratora opowieści, po czym melodia powraca do swojej pierwotnej, posępnej harmonii; żywioł kobiecy zostaje spacyfikowany przez męską melancholię. Ton, z jakim Świetlicki wypowiada nieobecne w wierszu słowa: „Dlaczegóż by miała zdejmować płaszczyk tak od razu?/ Dlaczegóż by miała zdejmować płaszczyk?" może sugerować, że kobieta wielokrotnie postępowała w ten sposób, a co za tym idzie - obelga zawarta w refrenie być może jest skojarzona właśnie z jej osobą. Słowa „Gotuj się, kurwo, gotuj” ożywiają utwór, Świetlicki wykrzykuje je przy mocnym, rockowym akompaniamencie, niejako użyczając swojego głosu sfrustrowanemu bohaterowi. Absurdalna, patowa sytuacja, w której znalazł się mężczyzna nie bawi odbiorcy, ale przez wzgląd na atmosferę całej piosenki domaga się rozumienia w konwencji metafory. Bohater cierpi na melancholię, apatię, wiedzie żywot człowieka-trupa, nie jest zdolny do budowania zdrowych relacji damsko-męskich, choćby nawet chciał, a kandydatka była wyjątkowo atrakcyjna. Kulminacyjny wrzask jest nie tyle uderzeniem skierowanym w kogokolwiek, ile ekspresją wewnętrznego napięcia, bólu istnienia, poczucia odosobnienia. „Gotuj się kurwo, gotuj” to manifest outsidera. Tego typu treści przewijają się obsesyjnie przez całą twórczość Świetlickiego ${ }^{10}$.

\section{SPEKTAKLO-KONCERTY}

Dla opisu przemian, jakim podlegają Odciski na scenie koncertowej, najistotniejszymi kwestiami są ironia wpisana w tekst utworu, podwójnie kodowane znaczenie, wspomniana absurdalna sytuacja poetycka oraz potencjał performatywny wiersza. Komponenty te pozwalają zaistnieć Odciskom na scenie w bardzo wielu wariantach interpretacyjnych i medialnych.

Za pierwszy z przykładów niech posłuży koncert Świetlików w krakowskim klubie Forty Kleparz z 30 listopada 2011 roku. Wykonania poszczególnych utworów były wówczas podporządkowane motywowi głównemu koncertu, który wyniknął spontanicznie (czy na pewno?) ze słów Świetlickiego: „Tak, to praw-

${ }^{10}$ Podmiot wierszy Świetlickiego często jest porównywany do filmowej kreacji Humphrey’a Bogarta w Casablance. Podobnie jak Richarda „Ricka” Blaine’a, cechuje go melancholia, tęsknota za utraconą, romantyczną miłością; urażona duma czyni z niego człowieka zgorzkniałego, niedostępnego, gruboskórnego w stosunku do kobiet, na pozór niewrażliwego. 
da, nie lubimy grać w Krakowie. Zresztą z wzajemnością". Prowokacyjna wypowiedź na wstępie skłoniła odbiorców do reakcji, ustosunkowania się wobec wyznania wokalisty. Ironiczna deklaracja podyktowała konstrukcję całego koncertu, podczas którego 32 zapowiedziane piosenki wykonywane były naprędce, w największym skrócie, a w przewie między utworami muzycy popędzali się i krytykowali za zbytnią rozwlekłość. Podczas jednej z piosenek, Świetlickiego zastąpił przy mikrofonie gitarzysta Grzegorz Dydych, twierdząc, że ,załatwi to szybciej". Muzycy grali na instrumentach, ale także odgrywali role, które narzuciła im inicjalna deklaracja Świetlickiego. Koncert będący spójną, przemyślaną całością, podporządkowany motywowi przewodniemu, łączący prezentację piosenek z quasi-aktorskim zachowaniem członków zespołu przybliża wydarzenie do medium teatralnego. Na uwagę zasługuje sceniczna postać Świetlickiego, współlidera i frontmana zespołu, obdarzonego aparycją oraz elementami biografii głosu mówiącego wiersze poety oraz Mistrza z jego powieści kryminalnych. Podczas koncertu Świetlicki wyposażony jest w atrybuty charakterystyczne dla bohaterów swojej literatury - czarny ubiór, ciemne okulary, papieros (Camel) w ustach. Tym samym kwestionuje granice między życiem a sztuką, a także między poszczególnymi dziedzinami sztuki (mediami). Dominantą tego typu wystąpienia staje się zdarzeniowość, istotą - fizyczna współobecność uczestników wydarzenia. Interakcja jaka między nimi zachodzi determinuje ostateczny kształt kreowanego na żywo dzieła sztuki. Koncert staje się spektaklem, a spektakl performansem.

W tak zaaranżowanym kontekście poszczególne utwory nabierają nieoczekiwanych znaczeń i przybierają zaskakujące formy. Sens piosenki jest wystawiony na pastwę sytuacji, zależy od chwilowego nastawienia wykonawcy, reakcji publiczności i mnóstwa nieplanowanych czynników; jest chwilowy i płynny. Podczas wspomnianego koncertu Odciski z braku czasu zostały zaprezentowane w skrótowej formie, Świetlicki w kilku zdaniach opowiedział zawierającą się w nich historię, zarysował sytuację bohaterów, po czym jednokrotnie zabrzmiał refren. Tym samym podkreślony został fabularny potencjał wiersza, natomiast zupełnie usunięty bagaż emocjonalny, zawarty właśnie w melancholijnej rozwlekłości zwrotek. Opowieść potraktowano jako banał, na który nie warto przeznaczać więcej czasu, co oczywiście było zabiegiem na wskroś ironicznym, być może skierowanym pod adresem krytyków twórczości Świetlickiego, a zaistniałym na mocy cichego porozumienia między wykonawcą a świadomą wartości tej piosenki publiką.

Swoboda formalna i rozszczepienie znaczeniowe Odcisków uprawomocniają wiele całkiem odmiennych realizacji scenicznych utworu. Zapoznając się z zarejestrowanymi fragmentami koncertów Świetlików, umieszczonymi na serwisie YouTube, można zauważyć, że sam Świetlicki często wykonuje piosenkę całkowicie poważnie, w wersji nie odbiegającej zanadto od nagrania płytowego. Wystarczy jednak drobny bodziec - pomyłka, komentarz słuchacza - by wyko- 
nawca wydobył z utworu pokłady humoru. W ludycznej wersji Odcisków zwykle znacznie częściej i w najmniej oczekiwanych miejscach pojawia się konstrukcja: „Dlaczegóż by nie”, a także pominięta zostaje kwestia: „Odciski robią mu się na sercu od takich historii" - wskazująca jednoznacznie na tragiczny wymiar sytuacji bohatera.

Tekst Odcisków doskonale nadaje się także do przedstawienia bez muzyki, w charakterze monodramu. Wspomniana mieszanka pierwiastka zabawowego i egzystencjalnego oraz niedorzeczność opisanej sytuacji skłaniają, by dostrzec w utworze związki z konwencją teatru absurdu, który ,Znosząc ostatecznie granicę między komedią a tragedią, [...] pozwolił opisać kondycję człowieka jako komediowo-tragiczną. Współczesnym odpowiednikiem antycznej tragedii stała się metafizyczna farsa - traktująca o - [...] tragicznej niepewności człowieka, który stoi na pustej scenie niepewny prawdziwości wszystkiego, co go otacza [...]. Kwestionujący na koniec swoją własną realność, okazuje się tragicznym bohaterem komicznej gry pozorów istnienia"11. Sytuacja poetycka Odcisków rzeczywiście jest niepewna ontologicznie, przypomina senny koszmar; odczucie to podjudza obecne w tekście piosenki, hipnotyzujące powtarzanie frazy: ,płomień płonie, płomień płonie, płomień płonie”, a także woda w czajniku, niejako wyjęta spod praw fizyki. Narrator opowieści ma kompetencje ironicznego demiurga - sam kreuje sytuację, obsadza bohaterów w niezręcznych rolach i szydzi z ich zachowań („Haha, jeżeli można podpalić wodę, podpala wodę”); jest wszechwiedzący i niezdefiniowany.

Absurd sytuacji wywołuje śmiech odbiorców w przypadku teatralnego wykonania Odcisków w ramach przedstawienia Czynny do odwołania w reżyserii Piotra Bikonta ${ }^{12}$. Wiesio - bohater wywiedziony z prozy Świetlickiego - jest postacią jednoznacznie komiczną, karykaturalną. To jemu w udziale przypada zaprezentowanie tekstu wiersza. Postać wyraźnie naznaczona kryzysem męskości („on nie jest gejem, on tylko aspiruje”), której każde słowo budzi uśmiech politowania, kierunkuje sposób odbioru Odcisków. Monodram Wiesia to farsowa miniaturka o rozterkach współczesnego, niedojrzałego do kontaktów z kobietami mężczyzny; podszyta pesymizmem, ale sama w sobie - niezwykle zabawna.

Jeszcze dalej w swojej interpretacyjnej inwencji poszedł Jakub Klebba uczestnik 53. Ogólnopolskiego Konkursu Recytatorskiego. W serwisie YouTube można obejrzeć jego pełne ekspresji i zmian w tekście wystąpienie, utrzymane w konwencji skeczu kabaretowego ${ }^{13}$. Wiersz w jego wykonaniu wywołuje lawinę śmiechu, nawet w momentach, w których trudno byłoby się spodziewać takiej reakcji odbiorców (np. na słowa: „Odciski robią mu się na ustach od tych papie-

${ }^{11}$ A. Kraje w s ka, Wstęp [w:] Dramat i teatr absurdu w Polsce, Poznań 1996, s. 13, 26.

${ }^{12}$ P. B ik on t, Czynny do odwołania - wg tekstów Marcina Świetlickiego. Teatr Powszechny, Warszawa, prem. 24 marca 2012 r.

13 J. Kle b b a, [53 OKR], Odciski - Marcin Świetlicki, online. Protokół dostępu: www.youtube.com/watch?v=Uzutv4cJ3ok, 20 maja $2012 \mathrm{r}$. 
rosów"). Przykład to o tyle ciekawy, że na jego podstawie można zaobserwować społeczne nastawienie do tego typu zabiegów, wyrażone w komentarzach pod filmem. Internauci najczęściej krytykują niewłaściwe zachowanie publiczności, która - ich zdaniem - błędnie oceniła znaczenie wiersza, a w błąd wprowadziła ją kabaretowa wersja Odcisków, również będąca nadużyciem. Jeden z komentatorów stwierdził: „Recytacja wierszy Świetlickiego powinna być karana”, inny daje wykonawcy konkretne rady: „To nie jest kabaret, to jest smutny tekst, trzeba go z powagą recytować, a nie latać po scenie jak małpka. Na krześle mogłeś usiąść, zapalić papierosa i opowiadać”. Nie brakuje jednak entuzjastów niekonwencjonalnego podejścia do wiersza - ciachoPl broni recytatora: „To jego interpretacja - sama w sobie jest trafiona. Przewaga komizmu nad dramatyzmem, jak dla mnie, jeszcze podwyższa wartość interpretacji. Idąc w stronę farsy, Kuba zyskał dodatkowo sympatię publiczności”; podobne stanowisko prezentuje Incusia: „Reakcja publiczności przecież jest prawidłowa. Świetlicki bawi się słowem. To naprawdę jest zabawne, a Twój występ jest świetny”.

Trudno powiedzieć, jak do wykonania Jakuba Klebby ustosunkowałby się sam Świetlicki, jednak abstrahując od intencji autorskiej należy przyznać, że tekst Odcisków niesie w sobie również taką, skrajną możliwość interpretacyjną. Wiersz jest niejako „zaprogramowany” na różnorakie realizacje przy użyciu różnorodnych mediów, na żywiołowe i sprzeczne reakcje publiczności, czego dowodem są koncerty Świetlików i cała twórczość Świetlickiego oraz co stanowi jedno z kryteriów (a może konsekwencji) zaistnienia dzieła sztuki w przestrzeni performatywnej.

\author{
Malwina Mus \\ POEM-SONGS AND SHOW-CONCERTS - \\ ERRATIC MEDIA COMPOSITIONS BY MARCIN ŚWIETLICKI
}

Summary

In Marcin Świetlicki's artistic work of the traditional poetic form has been transformed under the impact of new media. They have influenced the themes of his poems, for better or for worse as the case may be, and the construction of his poetic images, which tend represent events 'through the camera eye'. These devices are the artist's response to the broadening of perceptual capabilities of his audiences, habitual 'movie-watchers' who 'think both optically and aurally'.

What requires even more refinement and extraordinary self-awareness, is the planning of alternate versions of a given work to suit the various media. For example, thanks to its ironies, double-coded meaning, absurd poetic situation, and big performative potential the poem 'Calluses' can change its tone and message as a song, a miniature drama or a cabaret sketch - without a single alteration in its text. 